
\title{
28 Research Square \\ Effect of Human Umbilical Cord Mesenchymal Stem Cell Exosomes on Aerobic Metabolism of Human Retinal Pigment Epithelial Cells
}

Lian Liu

Department of Ophthalmology, First affiliated Hospital of Jinan University https://orcid.org/0000-0002-

5774-7602

Chun-lan Liang

The First Affiliated Hospital of Jinan University

Wei Fan

Hunan Aerospace Hospital

Jing-Xiang Zhong ( $\nabla$ zjx85221206@126.com )

The First Affiliated Hospital of Jinan University

\section{Research Article}

Keywords: HUCMSC exosomes, ARPE-19 cells, Oxidative damage, Aerobic metabolism, Respiratory chains complex enzyme activity, ATP synthesis

Posted Date: December 6th, 2021

DOI: https://doi.org/10.21203/rs.3.rs-1108949/v1

License: (1) This work is licensed under a Creative Commons Attribution 4.0 International License. Read Full License 


\section{Abstract \\ Purpose}

To investigate the effect of exosomes secreted by human umbilical cord mesenchymal stem cells (HUCMSC-Exo) on aerobic metabolism of cobalt chloride $\left(\mathrm{CoCl}_{2}\right)$-induced oxidative damage in human retinal pigment epithelial cell line ARPE-19, and to explore the protective mechanism of HUCMSC-Exo on oxidative damage in ARPE-19 cells.

\section{Methods}

HUCMSC-Exo were extracted and identified; JC-1 flow cytometry was used to detect the effects of exosomes with different concentrations on the apoptosis of oxidatively damaged ARPE-19 cells. The effects of exosomes with different concentrations on the activity of oxidative metabolic enzymes (oxidative respiratory chain complexes I, III, IV, and V) and ATP synthesis in oxidatively damaged ARPE-19 cells were detected by spectrophotometry.

\section{Results}

Under transmission electron microscope, HUCMSC-Exo were round and oval membrane vesicles with diameters of about 40-100 nm. Western blot results showed that HUCMSC-Exo expressed specific marker proteins CD63 and CD9; The proportion of apoptosis in the high-concentration exosomes intervention group was significantly lower than that in the injury non-intervention group; in $50 \mu \mathrm{g} / \mathrm{mL}$ and $100 \mu \mathrm{g} / \mathrm{mL}$ exosome intervention group, ATP synthesis were significantly different from the control group $(P<0.05)$. The activities of mitochondrial complex I, IV, and V in high concentration exosomes intervention groups were higher than those in other concentration intervention groups.

\section{Conclusion}

HUCMSC-Exo had a certain protective effect on ARPE-19 cells induced by $\mathrm{CoCl}_{2}$ in vitro. The protective mechanism of HUCMSC-Exo on oxidative damage ARPE-19 cells might be through saving its aerobic metabolic function, restoring cell ATP synthesis, and improving the ability of cells to repair damage and deal with the hypoxic environment.

\section{Introduction}

Retina is one of the tissues with high oxygen demand. The balance between oxygen supply and oxygen consumption can maintain retinal homeostasis. Once this balance is destroyed, it will lead to many retinal diseases[1]. Oxidative stress produced by this large amount of ROS is associated with the 
pathogenesis of various eye diseases, such as glaucoma, diabetic retinopathy (DR), age-related macular degeneration (AMD), and the retinopathies[2]. For a variety of reasons, the retina is particularly vulnerable to oxidative damage[3]. Oxidative stress may be the key factor leading to PRE dysfunction-related retinal diseases[4]. Current cellular strategies for protection against oxidative damage include antioxidants, molecular repair (removal or repair of oxidation-modified biomolecules to counteract functional effects), and cell replacement (using stem cells or progenitor cell populations)[5].

Exosomes have attracted the attention of researchers due to their powerful biological functions, such as tissue repair, inhibition of inflammation, and regulation of immunity. Exosomes are vesicles with the lipid bilayer structure of about $40 \sim 100 \mathrm{~nm}$ in diameter[6]. It is secreted by a variety of cell lines and cell types, including tumor cell lines, stem cells, and neurons. Human umbilical cord Mesenchymal Stem Cells (HUCMSCs) are a kind of multifunctional stem cells that exist in neonatal umbilical tissue. Compared with other sources of mesenchymal stem cells, such as bone marrow, adipose tissue, and so on, HUCMSCs have obvious advantages of lost cost, easy obtained, non-invasive procedure to the donors, and representing the noncontroversial source of mesenchymal stem cells[7]. HUCMSCs have a stronger expansion of capacity, lower immunity than bone marrow mesenchymal stem cells (BMSCs)[8].

Because the mesenchymal stem cells(MSCs) and their exosomes (MSCs-Exo) had a similar function[9], this study used HUCMSC-Exo to explore the protection mechanism against oxidative damage in APPE-19 cells.

\section{Materials And Methods}

\section{HUCMSCs-Exo purification and identification}

Briefly, HUCMSCs were cultured in a 5\%C02 incubator at $37^{\circ} \mathrm{C}$ in DMEM/F12 medium containing $10 \%$ fetal bovine serum (FBS) and 1\% double-antibody. 48 hours before extraction of the 4-10 generation hUCMSCs with good growth, the original medium was discarded and replaced with DMEM/F12 medium containing $10 \%$ exosomal serum (Exo-FBS) and $1 \%$ double antibody. After $48 \mathrm{~h}$ of cell culture, the culture medium was collected and put into the $15 \mathrm{ml}$ centrifuge tube. The cells and cell fragments were removed by $1000 \mathrm{rpm}$ centrifugation for $10 \mathrm{~min}$ at $4{ }^{\circ} \mathrm{C}$. The supernatant was prepared and filtered to the ultrafilter tube through a $0.22 \mu \mathrm{m}$ aseptic membrane. The exosome concentration was collected by centrifugation at $4000 \mathrm{rpm}$ for $8-10 \mathrm{~min}$ at $4^{\circ} \mathrm{C}$. After adding exosome extraction reagent ExoQuick-TC, the mixture was taken out after standing for at least $12 \mathrm{~h}$ and centrifuged at $10000 \mathrm{rpm}$ for $30-40 \mathrm{~min}$ at $4^{\circ} \mathrm{C}$. the bottom precipitate was collected, resuspended with $100-500 \mu l$ phosphate buffer saline (PBS) and stored in the $-80^{\circ} \mathrm{C}$ ultra-low temperature refrigerator for later use.

\section{Characterization of HUCMSCs-Exo}

The exosomes stored in $-80^{\circ} \mathrm{C}$ were quickly moved into a $37^{\circ} \mathrm{C}$ thermostat water bath for about 1 min, and the freezing tube was gently shaken until it melted completely. The exosome suspension was 
prepared by diluting the exosome samples with PBS buffer at 1:10 20. The morphological characteristics of exosomes were detected with transmission electron microscopy (TEM).

\section{Quantification and detection of exosomes protein}

The exosomes were lysed with RIPA lysis buffer containing protease inhibitors, and A562 was determined by Microplate Reader. The protein concentration of the exosomes was calculated according to the standard curve. Western blot was used to detect the expression of CD63 and CD9 in the exocrine after quantification.

\section{Establishment of oxidative damage model of ARPE-19 cells}

APRE-19 cells in the logarithmic growth phase were digested and centrifuged to form a single-cell suspension and inoculated in 96-well plates. After the cells were adherent overnight, the original medium was absorbed and replaced with the medium containing different concentrations $(0,50,100,200,400,800)$ $\mu \mathrm{mol} / \mathrm{L}$ of $\mathrm{CoCl}_{2}$. Each group was set up 5 holes and incubated at $37{ }^{\circ} \mathrm{C}$ and in $5 \% \mathrm{CO}_{2}$ incubator for 24 hours. Each well was incubated with $10 \mu \mathrm{l} \mathrm{CCK}-8$ for 30 min at $37^{\circ} \mathrm{C}$ in $5 \% \mathrm{CO} 2$ incubator. A450 was determined by Microplate Reader. The survival rate of APRE-19 cells was calculated, and the concentration of $50 \%$ cell survival rate was used as the optimum concentration of $\left(\mathrm{CoCl}_{2}\right)$-induced oxidative damage of ARPE-19 cells.

\section{Measurement of mitochondrial membrane potential (MMP)}

The cells were divided into six groups: normal group, non-intervention group $\left(\mathrm{CoCl}_{2}\right.$-damaged cells were cultured for $24 \mathrm{~h}$ without changing the original medium), $0 \mu \mathrm{g} / \mathrm{mL}$ exosome intervention group (the original medium was abandoned after $24 \mathrm{~h}$ of $\mathrm{CoCl}_{2}$-damaged cells, and a new medium without exosomes was added for further culture for $24 \mathrm{~h}$ ), $25 \mu \mathrm{g} / \mathrm{mL}$ exosome intervention group (the original medium was abandoned after $24 \mathrm{~h}$ of $\mathrm{CoCl}_{2}$-damaged cells, and the medium with $25 \mu \mathrm{g} / \mathrm{mL}$ exosome concentration was added for further culture for $24 \mathrm{~h}$ ), $50 \mu \mathrm{g} / \mathrm{mL}$ exosome intervention group (the original medium was abandoned after $24 \mathrm{~h}$ of $\mathrm{CoCl}_{2}$-damaged cells, and $50 \mu \mathrm{g} / \mathrm{mL}$ exosome concentration was added to the medium for further culture for $24 \mathrm{~h}$ ), $100 \mu \mathrm{g} / \mathrm{mL}$ exosome intervention group (the original medium was abandoned after $24 \mathrm{~h}$ of $\mathrm{CoCl}_{2}$-damaged cells, and the medium with the concentration of $100 \mu \mathrm{g} / \mathrm{mL}$ exosome was added for further culture for $24 \mathrm{~h}$ ). The adherent ARPE-19 cells were digested by $0.25 \%$ trypsin-0.2EDTA and suspended with $0.5 \mathrm{ml}$ cell culture medium. 5, 5',6,6'-tetrachloro-1,1',3,3'tetraethylbenzimidazolcarbocyanine iodide (JC-1) (BD Biosciences Pharmingen, San Diego, CA, USA) solution of $0.5 \mathrm{ml}$ was added, mixed, and then cells were incubated at $37^{\circ} \mathrm{C}$ for 20 minutes away form the light. Then, cells were treated with JC-1 staining buffer and analyzed by flow cytometry[10].

\section{Activity detection of oxidative respiratory chains complex}

The activity of $\nabla, \nabla, \nabla$, and $\nabla$ in the mitochondrial respiratory chains complex were determined by spectrophotometry with reference to the method of Vyatlina et al.[11] 10-20 $\mu \mathrm{g}$ of mitochondrial protein 
was added into the buffer solution with a final volume of $2 \mathrm{~mL}$, and distilled water was used as a blank tube to correct the absorbance to 0 point. The changes of absorbance values at wavelength of $340 \mathrm{~nm}$ and $550 \mathrm{~nm}$ for $3 \mathrm{~min}$ were measured, respectively. The unit of enzyme activity was nmol/min/ $10^{\wedge} 4 \mathrm{cell}$.

\section{Detection of ATP synthesis quantity}

Cellular extraction of ATP: First, the cells were collected into the centrifuge tube, the supernatant was excluded, and $1 \mathrm{ml}$ of the acid extract was added into the 5 million cells at a ratio of 500-1000:1. The cells were crushed by ultrasonic for $1 \mathrm{~min}$ (ice bath, intensity $20 \%$ or $200 \mathrm{~W}$, ultrasonic $2 \mathrm{~S}$ stopped for $1 \mathrm{~s}$ ). The cells were centrifuged at $8000 \mathrm{~g}$ at $4^{\circ} \mathrm{C}$ for $10 \mathrm{~min}$. The supernatant was integrated into another centrifuge tube, and an equal volume of alkaline extract was added to neutralize and mix. The supernatant was centrifuged at $8000 \mathrm{~g}$ at $4^{\circ} \mathrm{C}$ for $10 \mathrm{~min}$, then the supernatant was taken and placed on ice to be measured.

ATP synthesis assay: Spectrophotometer preheat for more than $30 \mathrm{~min}$, adjust the wavelength to $700 \mathrm{~nm}$, distilled water zero. Preparation of chromogenic agent: according to the volume of proposed chromogenic agent (sample number $* 0.87 \mathrm{ml}$ ), reagent $4(\mathrm{ml})$ :reagent $5(\mathrm{ml})=1: 5$ should be prepared before use. Sample determination: The mixture was thoroughly mixed and water bath was performed at $37^{\circ} \mathrm{C}$ for $30 \mathrm{~min}$. After the water bath at $37^{\circ} \mathrm{C}$ for $20 \mathrm{~min}$, the absorbance value of each tube was measured at $700 \mathrm{~nm}$. One blank tube and one standard tube are made respectively, and one pair of care is set for each measuring tube. Calculation of ATP content $\left(\mu \mathrm{mol} / 10^{\wedge} 4\right.$ cell $\left.* 10\right)=[S *(\mathrm{M}-\mathrm{C}) /(\mathrm{A}-\mathrm{B}) * \mathrm{~V} 1] /(500 * \mathrm{~V} 1 / \mathrm{V} 2)=0.004 *$ $(\mathrm{M}-\mathrm{C}) /(\mathrm{A}-\mathrm{B})$. M: standard liquid concentration, $1 \mu \mathrm{mol} / \mathrm{mL}, \mathrm{V} 1$ : solution in the reaction system, $0.03 \mathrm{~mL}$, V2: extraction liquid volume, $0.2 \mathrm{~mL}$, V3: serum (slurry) volume, $0.1 \mathrm{ml}$.

\section{Statistical analysis}

The statistical software SPSS 19.0 (IBM, Armonk, NY, USA) was used to analyze data. The results are represented as mean $\pm S D(x \pm s)$. For comparison of the different groups, statistical comparisons were performed by one-way ANOVA. In these analyses, $\mathrm{P}<0.05$ was considered statistically significant.

\section{Results}

\section{Characteristics of exosomes}

Electron microscopy demonstrated that HUCMSCs-Exo were round or oval membranous vesicles with diameters between 40 100nm (Fig. 1A-D). Western blot analysis confirmed that the HUCMSCs-Exo expressed CD63 and CD9 (Fig .1E).

\section{Optimal damage concentration of $\mathrm{CoCl}_{2}$ in ARPE-19 cell model}

Cells were treated with six different concentrations $(0 \mu \mathrm{g} / \mathrm{mL}, 50 \mu \mathrm{g} / \mathrm{mL}, 100 \mu \mathrm{g} / \mathrm{mL}, 200 \mu \mathrm{g} / \mathrm{mL}, 400 \mu \mathrm{g} / \mathrm{mL}$ and $800 \mu \mathrm{g} / \mathrm{mL}$ ) of $\mathrm{CoCl}_{2}$ for 24 hours and then incubated with $10 \mu \mathrm{L} \mathrm{CCK} 8$ for $30 \mathrm{~min}$. The survival rate 
of ARPE-19 cells were $(80.94 \pm 6.87) \%,(87.37 \pm 2.81) \%,(93.38 \pm 4.28) \%,(80.26 \pm 4.67) \%,(50.71 \pm 2.33) \%$ and $(25.06 \pm 3.75) \%$.

As shown in Fig .2, survival rate of ARPE-19 cells treated with $100 \mu \mathrm{g} / \mathrm{mL}, 400 \mu \mathrm{g} / \mathrm{mL}$ and $800 \mu \mathrm{g} / \mathrm{mL}$ $\mathrm{CoCl}_{2}$ concentrations were statistically significant compared with the control group $(P<0.05) .400 \mu \mathrm{mol} / \mathrm{L}$ and $800 \mu \mathrm{mol} / \mathrm{L} \mathrm{CoCl}_{2}$ concentrations significantly decreased the survival rate of ARPE-19 cells $(P<0.01)$. When the $\mathrm{CoCl}_{2}$ concentration is $400 \mu \mathrm{mol} / \mathrm{L}$, the survival rate of ARPE- 19 cells is $50 \%$, Which was chosen to be the optimal concentration for oxidative damage.

\section{Effect of exosomes on the morphology of APRE-19 cells injured by $\mathrm{CoCl}_{2}$}

Normal ARPE-19 cells were fusiform or polygonal monolayer adherent cells with a clear outline. The cytoplasm might contain pigment, namely lipofuscin, which was brown and mostly located in the inner side of the cell (Fig .3A). When $400 \mu \mathrm{g} / \mathrm{mL} \mathrm{CoCl}{ }_{2}$ was added, the number of ARPE-19 cells decreased, the space widened, the arrangement was disordered, the cells shrank and the nuclei aggregated (Fig .3B). After treated with exosome $(0 \mu \mathrm{g} / \mathrm{mL}, 25 \mu \mathrm{g} / \mathrm{mL}, 50 \mu \mathrm{g} / \mathrm{mL}$ and $100 \mu \mathrm{g} / \mathrm{mL})$ respectively, ARPE-19 cells morphology was similar to the normal group, with clear cell boundaries and increased cell numbers (Fig. $3 C-F)$. The cell morphology of the $50 \mu \mathrm{g} / \mathrm{mL}$ and $100 \mu \mathrm{g} / \mathrm{mL}$ exosome intervention groups were similar to that of the normal group, with clear cell boundaries and increased cell number.

\section{Effect of exosome on the MMP of ARPE-19 cells injured by $\mathrm{CoCl}_{2}$}

MMP detection of the three groups treated with different concentrations of exosomes $(0 \mu \mathrm{g} / \mathrm{mL}$, $25 \mu \mathrm{g} / \mathrm{mL}, 100 \mu \mathrm{g} / \mathrm{mL}$ ) and non-intervention group showed that the proportion of apoptosis were (25.5 $\pm 0.56) \%,(21.4 \pm 0.28) \%,(12.00 \pm 0.71) \%$ and $(11.32 \pm 0.21) \%$. Compared with the normal group $(6.57 \pm 0.24) \%$, there were statistically significant difference $(P \otimes 0.01)$. The result of the $50 \mu \mathrm{g} / \mathrm{mL}$ exosome intervention group was $(6.45 \pm 0.35) \%$, which was not significantly different from that of the normal group ( $P>0.05$ ). There was significant difference between the $0 \mu \mathrm{g} / \mathrm{mL}$ and $25 \mu \mathrm{g} / \mathrm{mL}$ exosome intervention groups with non-intervention group ( $\mathrm{P} \otimes 0.01)$. Additionally, there was a significant difference between $50 \mu \mathrm{g} / \mathrm{mL}$ and $100 \mu \mathrm{g} / \mathrm{mL}$ exosome intervention groups with the $0 \mu \mathrm{g} / \mathrm{mL}$ exosome intervention group (P凶0.01) (Fig.4).

\section{Effect of exosome on the activity of oxidative respiratory chains complex in ARPE-19 cells injured by $\mathrm{CoCl}_{2}$}

Respiratory chain complex I, namely NADH-Co Q reductase or NADH dehydrogenase, is the main part of $\mathrm{O}^{2.32-}$ generated in the respiratory electron transport chain. Its activity reflects the state of respiratory electron transport chain and reactive oxygen species (ROS) production.

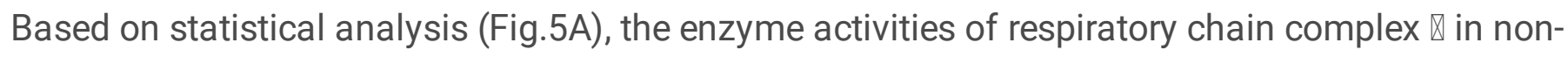
intervention group and $100 \mu \mathrm{g} / \mathrm{mL}$ exosome intervention group were respectively $(0.052 \pm 0.052)$ $\mathrm{nmol} / \mathrm{min} / 10^{\wedge} 4$ cell and $(0.066 \pm 0.00) \mathrm{nmol} / \mathrm{min} / 10^{\wedge} 4$ cell, which were significant differences between 


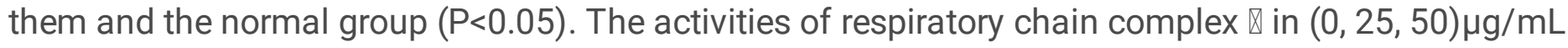

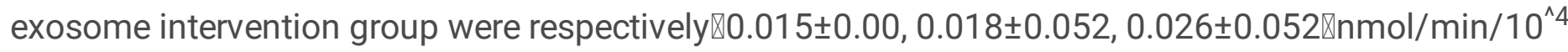
cell, which had no statistical difference with the normal groups (Pख0.05). However, there were significant differences between $(0,25,50$ and 100) $\mu \mathrm{g} / \mathrm{mL}$ exosome intervention group and non-intervention group $(\mathrm{P}<0.05) .50 \mu \mathrm{g} / \mathrm{mL}$ and $100 \mu \mathrm{g} / \mathrm{mL}$ exosome intervention group had significant differences with $0 \mu \mathrm{g} / \mathrm{mL}$ exosome intervention group $(P<0.05)$.

Respiratory chain complex $\otimes$, namely CoQ-cytochrome $\mathrm{C}$ reductase, is a common component of the main circuit and branch of mitochondrial respiratory electron transport chain. The activities of respiratory chain complex $\otimes$ in $(0,25,50$ and 100$) \mu \mathrm{g} / \mathrm{mL}$ exosome intervention groups were $(0.025 \pm 0.00,0.015 \pm 0.035$, $0.025 \pm 0.00,0.025 \pm 0.00) \mathrm{nmol} / \mathrm{min} / 10^{\wedge}$ cell respectively (Fig.5B), which had significant difference from normal group and non-intervention group $(P<0.05) .25 \mu \mathrm{g} / \mathrm{mL}$ exosome intervention groups also had significant difference with $0 \mu \mathrm{g} / \mathrm{mL}$ exosome intervention groups $(P<0.05)$.

Respiratory chain complex IV (cytochrome C oxidase), is a common component of the main and branch pathways of the mitochondrial respiratory electron transport chain. Activities of respiratory chain complex $\otimes$ in non-intervention group, $0 \mu \mathrm{g} / \mathrm{mL}$ exosome intervention group and $25 \mu \mathrm{g} / \mathrm{mL}$ exosome intervention group were respectively $(0.0044 \pm 0.00,0.0044 \pm 0.00,0.0044 \pm 0.00) \mathrm{nmol} / \mathrm{min} / 10^{\wedge}$ cell (Fig.5C), which was significant difference with the normal group $(P<0.05)$. There was no significant difference between normal group and $50 \mu \mathrm{g} / \mathrm{mL}$ or $100 \mu \mathrm{g} / \mathrm{mL}$ exosome intervention group $(P>0.05)$, activity of respiratory chain complex $\otimes$ of which were $(0.0067 \pm 0.031) \mathrm{nmol} / \mathrm{min} / 10^{\wedge} 4$ cell and $(0.0089$ $\pm 0.00) \mathrm{nmol} / \mathrm{min} / 10^{\wedge}$ cell respectively. However, there was significant differences between $100 \mu \mathrm{g} / \mathrm{mL}$ exosome intervention group with $0 \mu \mathrm{g} / \mathrm{mL}$ exosome intervention group and the non-intervention group $(\mathrm{P}<$ 0.05)

Respiratory chain complex $\mathrm{V}$, also known as F1F0-ATP synthase, is the key enzyme for mitochondrial oxidative phosphorylation to synthesize ATP. Activities of respiratory chain complex $V$ in non-intervention group, $0 \mu \mathrm{g} / \mathrm{mL}$ and $25 \mu \mathrm{g} / \mathrm{mL}$ exosome intervention group were $(0.0020 \pm 0.00,0.0010 \pm 0.00$ and 0.0020 $\pm 0.00) \mathrm{nmol} / \mathrm{min} / 10^{\wedge} 4$ cell(Fig.5D), which were no significant difference with the normal group $(P>0.05)$. The activities of respiratory chain complex $V$ in $50 \mu \mathrm{g} / \mathrm{mL}$ and $100 \mu \mathrm{g} / \mathrm{mL}$ exosome intervention group were $(0.017 \pm 0.0077)$ and $(0.078 \pm 0.00) \mathrm{nmol} / \mathrm{min} / 10^{\wedge} 4 \mathrm{cell}$, and had significant differences with the other groups $(P<0.05)$.

\section{Effect of exosome on ATP synthesis of ARPE-19 cells injured by $\mathrm{CoCl}_{2}$}

ATP is a complex high-energy compound, which widely exists in animals, plant microorganisms, and cultured cells. ATP is involved in many life processes and referred to as the "monetary molecular unit" for intracellular energy transfer. Measuring ATP content and calculating energy charge can reflect the state of energy metabolism. As shown in Fig. 6 , normal group had significant differences $(P<0.01)$ with the nonintervention group, $50 \mu \mathrm{g} / \mathrm{mL}$ and $100 \mu \mathrm{g} / \mathrm{mL}$ exosome intervention group, whose ATP synthesis were $\left(0.018 \pm 0.0041,0.013 \pm 0.0013,0.020 \pm 0.0016 \varangle \mu \mathrm{mol} / 10^{\wedge} 4\right.$ cells*10. However, there was no significant 
difference between normal group and $0 \mu \mathrm{g} / \mathrm{mL}$ or $25 \mu \mathrm{g} / \mathrm{mL}$ exosome intervention group ( $P>0.05)$, whose ATP synthesis were $(0.0036 \pm 0.00063)$ and $(0.0044 \pm 0.00032) \mu \mathrm{mol} / 10^{\wedge} 4$ cells ${ }^{\star} 10$. There was significant difference between $0 \mu \mathrm{g} / \mathrm{mL}, 25 \mu \mathrm{g} / \mathrm{mL}, 50 \mu \mathrm{g} / \mathrm{mL}$ exosome intervention group with the non-intervention group $(P<0.05)$. $0 \mu \mathrm{g} / \mathrm{mL}$ exosome intervention group had significant difference with $25 \mu \mathrm{g} / \mathrm{mL}$ and $50 \mu \mathrm{g} / \mathrm{mL}$ exosome intervention group $(P<0.05)$.

\section{Discussion}

In recent years, more and more evidence proved MSCs or MSCs-Exo could rescue the aerobic metabolism of damaged cells[12]. Arslan et al.[13] injected MSCs-Exo into the mouse model of myocardial infarction through the tail vein, and the results showed that the levels of ATP and NADH could be restored within 1 hour. This study also showed that MSCs-Exo enhanced the viability of reperfusion myocardium by reducing oxidative stress and increasing phosphorylated Akt and phosphorylated GSK-3 $\beta[13]$. Panfoli et al.[14] suggested that the UCMSCs-Exo of full-term neonates could express functional respiratory chain

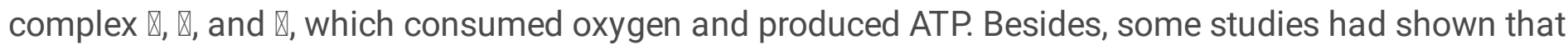
there were functional expressions of respiratory chains complexes and the tricarboxylic acid cycle (TCA cycle) enzymes in urinary exosomes, its proteomics showed that proteins were concentrated in certain specific functions, one of which was aerobic metabolism[15, 16].

The ability of exosomes to restore cellular aerobic metabolism may be due to their oxidative phosphorylation independent of mitochondria. Panfoli et al.[14]showed that ND4L, expressed by exosomes, was a complex \subunit encoded by DNA, indicating that the mechanism of oxidativephosphorylation (OXPHOS) in exosome membrane was the same as that in mitochondria. There was a supramolecular arrangement of the respiratory complex in the mitochondrial membrane, which could be transferred to endoplasmic reticulum (ER), through heterologous fusion between mitochondrial and ER, and eventually transferred to the exosomes body when sprouting in polyvessicles[14]. This may be one of the explanations for the origin of the exosome OXPHOS mechanism. Additionally, Islam et al. [17] reported that there was a gap junction between mitochondrial DNA and alveolar cells in human MSCs after acute lung injury, so mitochondrial transferred and exosome transferred might also play a role in restoring the aerobic metabolism of injured cells. If the MSCs-Exo could save the aerobic metabolism and restored the ATP synthesis of cells, it was hoped to improve the ability of cells to repair injuries and deal with the hypoxic environment, thereby promoting cell repair and regeneration and restoring their functions. This would provide a theoretical basis for the therapeutic efficacy of MSCs and MSCs-Exo in a variety of diseases.

Our results showed that the number of ARPE-19 cell death in the intervention group with high exosomes concentration was significantly lower than that in the non-intervention group, and the cell morphology was also closer to that of normal cells.

In the results of MMP detection, the proportion of apoptosis in the $50 \mu \mathrm{g} / \mathrm{mL}$ exosomes intervention group was closest to that of the normal group, but there was no significance between the two groups $(P>0.05)$. 
The date of other concentration groups $(0 \mu \mathrm{g} / \mathrm{mL}, 25 \mu \mathrm{g} / \mathrm{mL}$, and $100 \mu \mathrm{g} / \mathrm{mL})$ were statistically significant, and the proportion of apoptosis decreased with the increase of exosomes concentration. The enzyme

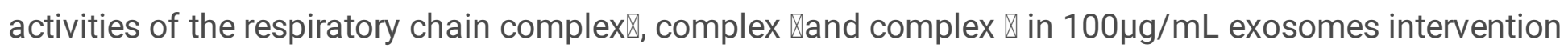
group were significantly higher than those in other groups. However, there was no significant change in

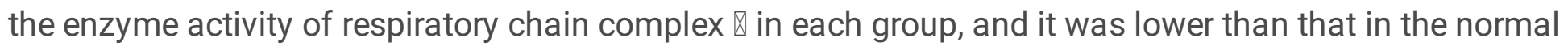
group. Also, the amount of ATP synthesis in the non-intervention group, $50 \mu \mathrm{g} / \mathrm{mL}$, and $100 \mu \mathrm{g} / \mathrm{mL}$ exosome intervention group were higher than that in other groups, and the ATP synthesis in $100 \mu \mathrm{g} / \mathrm{mL}$ exosomes intervention group was the highest. The above results suggested that the addition of exosomes at a certain concentration could restore the aerobic metabolism and ATP synthesis of ARPE-19 cells damaged by oxidation, and have a protective effect on the cells. Moreover, the MMP and the activity of the respiratory chain complex囚in the non-intervention group were higher than those in the low concentration exosomes intervention group, which might be due to the production of a certain amount of exosomes in ARPE-19 itself after oxidative damage. Due to the replacement of the original culture medium in the $0 \mu \mathrm{g} / \mathrm{mL}$ and $25 \mu \mathrm{g} / \mathrm{mL}$ exosomes concentration group, the exosomes produced by ARPE19 itself were removed, while the exosome concentration was lower, it might not be enough to have a significant effect on cell function. In this study, hUCMSC was "starved" before exosomes were extracted, exosome extraction can be improved by removing exosome serum for hUCMSC culture. Weiss ML et al. released cells from umbilical cord matrix by enzymatic degradation of extracellular matrix, and this improved isolation method can help to produce a sufficient number of exosomes[7]. Further experiments are needed to determine whether there are other more effective pretreatment methods.

It is remarkable that the therapeutic effect of MSCs is mainly mediated by paracrine of exosome[18]. And compared with MSCs, exosome is a kind of cell-free therapy, which has more advantages[19]. Our results showed that HUCMSC-Exo had a certain protective effect on ARPE-19 cells injured by $\mathrm{CoCl}_{2}$ in vitro. The protective mechanism may be to restore the amount of ATP synthesis and improve the ability of cells to repair damage and deal with hypoxic environment by saving their aerobic metabolic function.

\section{Declarations}

Acknowledgements: We are grateful to our colleagues for their helpful suggestions during the planning and editing of this work.

Founding: Supported by the National Natural Science Foundation of China (No.81970806, No.82101116), Fundamental Research Funds for the Central Universities $\llbracket$ No.21621052】

Conflicts of Interest: The authors declare that there is no conflict of interest.

Author Contributions: All authors contributed to the study conception and design. Material preparation, data collection and analysis were performed by [Wei Fan], [Lian liu]and [Chunlan Liang]. The first draft of this manuscript was written by [Chunlan Liang] and [Lian liu] and all authors commented on previous versions of the manuscript. All authors read and approved the final manuscript. 


\section{References}

1. Yu D Y,Cringle S J (2005)Retinal degeneration and local oxygen metabolism. Exp Eye Res 80 (6) 74551. https://doi.org/10.1016/j.exer.2005.01.018

2. Ung L,Pattamatta U,Carnt N, et al. (2017)Oxidative stress and reactive oxygen species: a review of their role in ocular disease. Clinical science (London, England : 1979) 131 (24) 2865-2883. https://doi.org/10.1042/cs20171246

3. Ambati J,Ambati B K,Yoo S H, et al. (2003)Age-related macular degeneration: etiology, pathogenesis, and therapeutic strategies. Surv Ophthalmol 48 (3) 257-93. https://doi.org/10.1016/s00396257(03)00030-4

4. Gong X,Draper C S,Allison G S, et al. (2017)Effects of the Macular Carotenoid Lutein in Human Retinal Pigment Epithelial Cells. Antioxidants (Basel) 6 (4). https://doi.org/10.3390/antiox6040100

5. Jarrett S G,Boulton M E (2012)Consequences of oxidative stress in age-related macular degeneration. Mol Aspects Med 33 (4) 399-417. https://doi.org/10.1016/j.mam.2012.03.009

6. Lee Y,El Andaloussi S,Wood M J (2012)Exosomes and microvesicles: extracellular vesicles for genetic information transfer and gene therapy. Hum Mol Genet 21 (R1) R125-34. https://doi.org/10.1093/hmg/dds317

7. Weiss M L,Medicetty S,Bledsoe A R, et al. (2006)Human umbilical cord matrix stem cells: preliminary characterization and effect of transplantation in a rodent model of Parkinson's disease. Stem Cells 24 (3) 781-92. https://doi.org/10.1634/stemcells.2005-0330

8. Chen M Y,Lie P C,Li Z L, et al. (2009)Endothelial differentiation of Wharton's jelly-derived mesenchymal stem cells in comparison with bone marrow-derived mesenchymal stem cells. Exp Hematol 37 (5) 629-40. https://doi.org/10.1016/j.exphem.2009.02.003

9. He G H,Zhang W,Ma Y X, et al. (2018)Mesenchymal stem cells-derived exosomes ameliorate blue light stimulation in retinal pigment epithelium cells and retinal laser injury by VEGF-dependent mechanism. Int J Ophthalmol 11 (4) 559-566. https://doi.org/10.18240/ijo.2018.04.04

10. Liu L,Sha X Y,Wu Y N, et al. (2020)Lycium barbarum polysaccharides protects retinal ganglion cells against oxidative stress injury. Neural regeneration research 15 (8) 1526-1531. https://doi.org/10.4103/1673-5374.274349

11. Vyatkina G,Bhatia V,Gerstner A, et al. (2004)Impaired mitochondrial respiratory chain and bioenergetics during chagasic cardiomyopathy development. Biochim Biophys Acta 1689 (2) 162-73. https://doi.org/10.1016/j.bbadis.2004.03.005

12. Lai R C,Yeo R W,Lim S K (2015)Mesenchymal stem cell exosomes. Semin Cell Dev Biol 40 82-8. https://doi.org/10.1016/j.semcdb.2015.03.001

13. Arslan F,Lai R C,Smeets M B, et al. (2013)Mesenchymal stem cell-derived exosomes increase ATP levels, decrease oxidative stress and activate PI3K/Akt pathway to enhance myocardial viability and prevent adverse remodeling after myocardial ischemia/reperfusion injury. Stem Cell Res 10 (3) 30112. https://doi.org/10.1016/j.scr.2013.01.002 
14. Panfoli I,Ravera S,Podestà M, et al. (2016)Exosomes from human mesenchymal stem cells conduct aerobic metabolism in term and preterm newborn infants. Faseb j 30 (4) 1416-24. https://doi.org/10.1096/fj.15-279679

15. Panfoli I,Ravera S,Bruschi M, et al. (2011)Proteomics unravels the exportability of mitochondrial respiratory chains. Expert Rev Proteomics 8 (2) 231-9. https://doi.org/10.1586/epr.11.1

16. Bruschi M,Santucci L,Ravera S, et al. (2016)Human urinary exosome proteome unveils its aerobic respiratory ability. J Proteomics 136 25-34. https://doi.org/10.1016/j.jprot.2016.02.001

17. Islam M N,Das S R,Emin M T, et al. (2012)Mitochondrial transfer from bone-marrow-derived stromal cells to pulmonary alveoli protects against acute lung injury. Nat Med 18 (5) 759-65. https://doi.org/10.1038/nm.2736

18. Yu B,Li X R,Zhang X M (2020)Mesenchymal stem cell-derived extracellular vesicles as a new therapeutic strategy for ocular diseases. World J Stem Cells 12 (3) 178-187. https://doi.org/10.4252/wjsc.v12.i3.178

19. Nuzzi R,Caselgrandi P,Vercelli A (2020)Effect of Mesenchymal Stem Cell-Derived Exosomes on Retinal Injury: A Review of Current Findings. Stem Cells Int 20208883616. https://doi.org/10.1155/2020/8883616

\section{Figures}

\section{Figure 1}

Morphology and size of exosomes under transmission electron microscopy and Western blot identification (A:×39000, B,C:×65000, D:×93000, E: Western blot identification of the HUCMSCs-Exo. Scale bars: $200 \mathrm{~nm})$ 


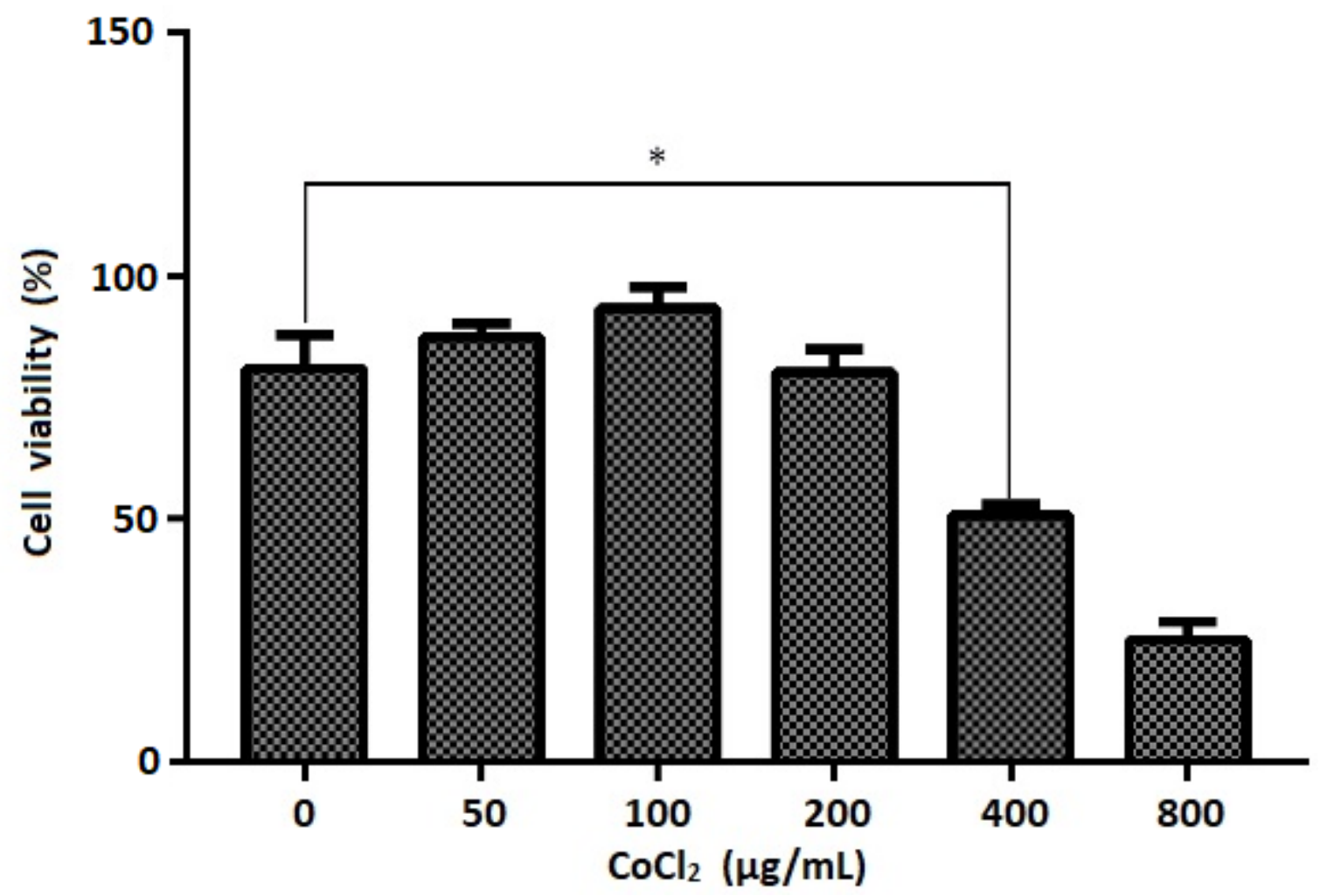

Figure 2

Cobalt chloride $(\mathrm{CoCl} 2)$ reduces the survival of ARPE-19 cells Cell viability of ARPE-19 cells was detected by cell counting kit-8, Data were presented as the mean $\pm S D(n=5)$ and analyzed by one-way ANOVA.

Figure 3

Effect of exosomes on CoCl2-induced APRE-19 cell morphology $(\times 400)$ A: normal APRE-19 B: $400 \mu \mathrm{g} / \mathrm{mL}$ $\mathrm{CoCl} 2$ damaged APRE-19 C: APRE-19 treated with 0 $\mathrm{\mu g} / \mathrm{mL}$ HUCMSCs-Exo D: APRE-19 treated with $25 \mu \mathrm{g} / \mathrm{mL}$ HUCMSCs-Exo E: APRE-19 treated with 50 $\mathrm{g} / \mathrm{mL}$ HUCMSCs-Exo F: APRE-19 treated with $100 \mu \mathrm{g} / \mathrm{mL}$ HUCMSCs-Exo

\section{Figure 4}

CoCl2 decreased MMP in ARPE-19 cells, an effect reversed by HUCMSCs-Exo was recorded. a: $p<0.01$, vs. normal group $b: p<0.01$, vs. non-intervention group $* *$ : $p<0.01$, vs. $0 \mu \mathrm{g} / \mathrm{mL}$ exosome intervention group

Figure 5 
Activity of cell respiratory chain complexin in each group ( $\left.{ }^{\star} \mathrm{P}<0.05\right)$ A: NADH dehydrogenase, $B$ : Cytochrome $\mathrm{C}$ reductase, $\mathrm{C}$ : Cytochrome $\mathrm{C}$ oxidase, D: F1F0-ATP synthase

\section{Figure 6}

ATP synthesis in each treated group $\left({ }^{\star} \mathrm{P}<0.05\right)$ 